\title{
Introduction to World Taekwondo Peace Corps
}

\author{
Jong-Hoon YU¹; Wojciech J. CYNARSKI2; Ferman KONUKMAN3; Takahiro KITAMURA4; Kibum CHO5; \\ Junhyung BAEK ${ }^{5}$ \\ ${ }^{1}$ Glenville State College, Glenville, WV (USA) \\ 2 University of Rzeszów (Poland) \\ ${ }^{3}$ Qatar University, Doha (Qatar) \\ ${ }^{4}$ National Institute of Fitness and Sports, Kanoya (Japan) \\ ${ }^{5}$ West Virginia University, WV (USA)
}

\section{5th IMACSSS World Scientific Congress Abstracts, Rio Maior (Portugal), October 6-8}

Section: Psychological, pedagogic and didactics in MA\&CS

Type: Oral communication

\section{Historical background}

The World Taekwondo Pace Corps (TPC) was created by the World Taekwondo Federation (WTF) President, Dr. Chungwon Choue, in 2008 to help enhance world peace and harmony, a deeper understanding of different cultures, and friendship around the world through taekwondo volunteer service (Cutler, 2012). He put a forth challenge to Taekwondo experts, many of whom were college and university students, to move away from their personal comfort zone, and to sacrifice for and share their talents for others in international community. In the same year, Dr. Choue's vision for the development of TPC was transformed into reality as the initial fifty-nine Korean Peace Corps volunteers were selected in both summer and winter sessions and dispatched in thirteen host countries. One year later, the World Taekwondo Peace Corps Foundation was established to increase funding to facilitate the development and expansion of the program. By the end of the 2014, there were fifteen hundred volunteers who had served the Taekwondo Peace Corps in many host countries (World Taekwondo Peace Corps Foundation, 2014).

\section{Volunteer dispatch and performance}

In general, the World Taekwondo Peace Corps Foundation sends their volunteers to diverse places based on a request for volunteer provided by local communities in host countries. Each team of TPC volunteers provides its training program and education to meet the host country's needs. Each team consists of four volunteers, three taekwondo experts and one language student and is then dispatched to assigned countries bi-annually, on both the short-term basis for two months and the mid-term period of six months.

Taekwondo Peace Corps volunteers are expected to be involved in teaching and community outreach. Although Taekwondo instruction is the primary mission of TPC volunteers in host countries, additional activities are meant to introduce Korean culture through Korean language lessons, traditional games, dance, traditional arts, food, the donation of equipment (i.e., uniforms and training pad targets). The use of educational books, and music materials are also a focus of this volunteer community outreach (Lee, 2014).

\section{Volunteer recruitment and training}

Taekwondo Peace Corps volunteers are chosen based on application materials and performance during interview by selection officers. Candidates must be college/university students who are over

*Email: jong-hoon.yu@glenville.edu 
the age of 18 and at least $3^{\text {rd }}$ black belt degree holder. They also must possess a good understanding of the value of volunteerism, as well as an ability to deepen the degree of their service and commitment, along with a genuine cultural sensitivity (Lee, 2014).

Selected volunteers are part of a one week training course to prepare them for overseas dispatch. In particular, they are trained in the fields of competition, poomsae, and taekwondo demonstration. The World Taekwondo Peace Corps Foundation covers the expenses of airfare to and from the country of service, whereas host countries cover the expenses of accommodations such as meals, lodgings and local transportation for volunteers.

\section{Volunteer recognition}

In its nine years of service, the Taekwondo Peace Corps has acquired a well-founded international reputation for successful overseas service through Taekwondo volunteers in developing countries and some more modern nations. In that sense, Taekwondo Peace Corps program has promoted a favorable world image of Taekwondo. World Taekwondo Federation was nominated for Peace and Sport Award at the 2012 Peace and Sport International Forum held in Sochi, Russia for the remarkable contribution to communities in developing countries made by its Taekwondo Peace Corps volunteers (Armstrong, 2013).

\section{Conclusion}

Returning volunteers described that participation in the Taekwondo Peace Corps as a great opportunity to recognize the importance of volunteer efforts and to learn and expand their world view. They also said how they gained much more than they gave during their service overseas (Lee, et al., 2013; Lim \& Seok, 2012; Seok, 2012). Finally, for the development and expansion of the program, the Taekwondo Peace Corps needs to include volunteers from multiple countries and extend their volunteer service to people from the most deprived countries and communities including refugee camps, orphanages, and war zones (Choue, 2010).

\section{References}

Armstrong, N.B. (2013). Taekwondo: The unity of body, mind and spirit. Seoul, Korea: Seoul Selection.

Choue, C. (2010, May). Proliferation of peace through sport. Paper presented at the U.N.-IOC Forum, Lausanne, Switzerland.

Cutler, M. (2012). A peace offering. Sportbusiness International, 181, 66-67.

Lee, E. J. (2014) A study on international taekwondo volunteer organization activities: Focusing on koica and tpc. Unpublished doctoral dissertation. Yong In University, Yongin-si, Korea.

Lee, J., Kim, M., Choi, J., Lee, J., Jang, Y., Jung, R., \& You, C. (2013). A case study of volunteer activities through taekwondo in abroad: Focused on case of tpc. Chung Cheong University Nonmunjip, 45, 233-253.

Lim, S. J., \& Seok, R. (2012). Taekwondo majors self-identity through experience of international taekwondo volunteering. Taekwondo Journal of Kukkiwon, 3(2), 35-52.

Seok, R. (2012). Research for global citizenship and self-identity through experience of international taekwondo volunteering. Unpublished doctoral dissertation, Kyung Hee University. Seoul, Korea.

World Taekwondo Peace Corps Foundation. (2014, May). 2014 result report of world taekwondo peace corps. Seoul, Korea: Author.

World Taekwondo Federation. (n.d.). Short-term dispatches. Retrieved from http://www.worldtaekwondofederation.net/development/tpc/tpc-dispatches/

Key words: Volunteer; service; culture; community; international; dispatch; Taekwondo; combat sports. 